\title{
SYNTHESIS OF TETRAHYDROHEXAGAMAVUNON-5 AND TETRAHYDROHEXAGAMAVUNON-7
}

\begin{abstract}
Ritmaleni ${ }^{1,2 *}$, Ian Praditya ${ }^{1}$, Haryono Wibowo ${ }^{1}$, Sardjiman ${ }^{1,2}$
1Pharmaceutical Chemistry

Section, Faculty of

Pharmacy, Gadjah Mada

University, Yogyakarta

55281, Indonesia

${ }^{2}$ Curcumin Research Center

(CRC), Faculty of Pharmacy,

Gadjah Mada University,

Yogyakarta 55281,

Indonesia

Submitted: 28-08-2014

Revised: 20-09-2014

Accepted: 05-12-2014

*Corresponding author

Ritmaleni

ABSTRACT

Synthesis of Tetrahydrohexagamavunon-5 (THHGV-5) and Tetrahydrohexagamavunone-7 (THHGV-7) were prepared by catalytic hydrogenation reaction on Hexagamavunon-5 (HGV-5) and Hexagamavunone-7 (HGV-7) by using gas $\mathrm{H}_{2}$ as source of hydrogen gas, $\mathrm{Pd} / \mathrm{C} 10 \%$ as metal catalyst and methanol as solvent at room temperature. According to previous study, Pd/C catalyst is more specific than other metal catalyst to reduce $a, \beta$ unsaturated double bond without reduction of its carbonyl functional group. The products were characterized by IR Spectroscopy, Gas Chromatography-Mass Spectroscopy (GCMS), 1D-NMR ( ${ }^{1} \mathrm{H}-\mathrm{NMR}$ and $\left.{ }^{13} \mathrm{C}-\mathrm{NMR}\right)$ and $2 \mathrm{D}-\mathrm{NMR}\left({ }^{1} \mathrm{H}-{ }^{13} \mathrm{C}\right.$ HMQC) Spectroscopy to determine the product structure molecules. According to the data of IR, GC-MS, ${ }^{1} \mathrm{H}-\mathrm{NMR},{ }^{13} \mathrm{C}-\mathrm{NMR}$ and ${ }^{1} \mathrm{H}-{ }^{13} \mathrm{C}$ HMQC spectra, the products are THHGV-5 and THHGV-7 as white crystalline powders.
\end{abstract}

Email:

ritmaleni@ymail.com

Key words:Tetrahydrohexagamavunon-5, Tetrahydrohexagamavunone-7, Hexagamavunon-5, Hexagamavunone-7

\section{INTRODUCTION}

Tetrahydrocurcumin (THC) is a main metabolite of curcumin. THC has a better antioxidant activity than curcumin itself (Sugiyama, et al., 1996) and its mechanism has been described by Yoysungnoen et al. (2008). THC also has some biological activities apart from antioxidant such as antidiabetic and antihyperlipidemia on diabetic mouse (Murugan and Pari, 2007), and anticancer with antiangiogenic mechanism (Yoysungneon et al., 2008). THC itself is normally isolated with curcumin from turmeric extracts of curcuminoids. THC is easier absorbed in gastrointestinal than curcumin (Okada et al., 2001) and showed that THC is more stable than curcumin in physiological buffer $\mathrm{pH} 7.2$ and blood plasma.

In our previous publication, there are almost fifty analogs curcumin that successfully been made (Sardjiman et al., 1997; Sardjiman et al., 2003; Sardjiman et al., 2004). These analogs have many different biological activities. Some of the analogs that we focus on are PGV-0, Hexagamavunone-5 (HGV-5) and Hexagamavunone-7 (HGV-7). PGV-0 is a promising anti-inflammatory agent, $\mathrm{HGV}-5$ has a potent antioxidant activity and HGV-7 is more potent as antibacterial agent against $S$. pneumonia than PGV-0 and curcumin (Sardjiman, 2000).

Some analogs of THC such as Tetrahydropentagamavunone- 0 (THPGV-0) and Tetrahydropentagamavunone-1 (THPGV1) have been also successfully synthesized in Curcumin Research Center, Faculty of Pharmacy, Gadjah Mada University, Yogyakarta, Indonesia (Ritmaleni and Simbara, 2010; Ritmaleni, et al., 2013). Its biological activities also have been investigated (Ritmaleni et al., 2013). THPGV-0 is made from PGV-0 and showed better antioxidant activity compared to PGV-0 and vitamin E. According to this, THHGV-5 and THHGV-7 might have biological activities better than HGV-5 and HGV-7. This research is aimed to synthesized Hexagamavunone-5 (HGV-5) and Hexagamavunone-7 (HGV-7).

\section{MATERIAL AND METHODS}

HGV-5 and HGV-7 (Curcumin Research Center, Faculty of Pharmacy UGM), Pd/C 10\% (Aldrich), hydrogen gas $\left(\mathrm{H}_{2}\right)$ (Samator, Yogyakarta), methanol (p.a., Merck), n-hexane (p.a., Merck), dichloromethane (p.a., Merck), ethyl acetate (p.a., Merck). 
<smiles>COc1cc(CCC(=O)CC(=O)CCc2ccc(O)c(OC)c2)ccc1O</smiles>

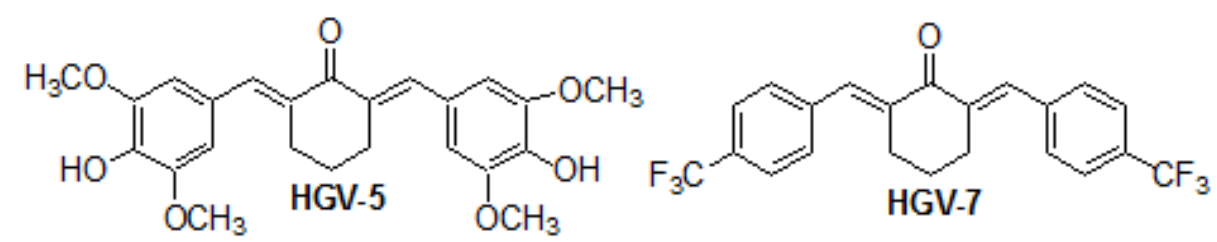

Figure 1. Chemical Structure of THC, THPGV-0, HGV-5 and HGV-7<smiles>[R]c1cc(/C=C2\CCC/C(=C\c3cc([R])c([R2])c([R])c3)C2=O)cc(CC2CCCC(Cc3cc([R3])c([R])c([R])c3)C2=O)c1</smiles>

HGV $-5 ; \mathrm{R} 1=-\mathrm{OCH}_{3}, \mathrm{R} 2=-\mathrm{OH}, \mathrm{R}_{3}=-\mathrm{OCH}_{3}$ HGV-7; R1 = -H, R2 = -CF3, $\mathrm{R}_{3}=-\mathrm{H}$

THHGV-5; R1 $=-\mathrm{OCH}_{3}, \mathrm{R} 2=-\mathrm{OH}, \mathrm{R}_{3}=-\mathrm{OCH}_{3}$ THHGV-7; R1 $=-H, R 2=-\mathrm{CF} 3, \mathrm{R}_{3}=-\mathrm{H}$

Figure 2. Hydrogenation Reaction of HGV-5 and HGV-7 to be THHGV-5 and THHGV-7

\section{General procedure}

This synthesis was done based on the published method (Ritmaleni and Simbara, 2010). In round bottom flask, HGV-5 or HGV-7 in $5.0 \mathrm{~mL}$ methanol p.a was added Palladium/Carbon (Pd/C) 10\% (10 mole \%). Hydrogen gas $\left(\mathrm{H}_{2}\right)$ in balloon was blown for three hours into the reaction mixture. The reaction was an auto indicator reaction; the color of reaction mixture is changing from yellow to colourless. Then, the mixture was filtered and the solvent was evaporated by using rotavapor. The products were isolated by Flash Column Chromatography and purified by recrystallization method. The structure elucidation of the targeted product was carried out by using Spectroscopy method (IR, GCMS, 1D-NMR ( ${ }^{1} \mathrm{H}-\mathrm{NMR}$ and $\left.{ }^{13} \mathrm{C}-\mathrm{NMR}\right)$ and 2D-NMR ( ${ }^{1} \mathrm{H}-{ }^{13} \mathrm{C}$ HMQC)).

\section{Synthesis of THHGV-5 [TRIVIAL]; 2,6- bis-(4'-Hydroxy-3',5'-dimethoxybenzil)- cyclohexanon [IUPAC]}

HGV-5 (250mg; 0.46mmol) in $\mathrm{MeOH}$ (5mL), Pd/C 10\% (49.72mg; $0.46 \mathrm{mmol})$, isolated by flash column chromatography
(Chloroform : Ethyl acetate (5:1), recrystallized from ethanol : water $\left(\mathrm{EtOH}: \mathrm{H}_{2} \mathrm{O}=2: 1 \mathrm{v} / \mathrm{v}\right)$, THHGV -5 as white crystalline powder; yielded $23 \%$ of THHGV-5; $R_{f}=0.60$ (kloroform : etil asetat $(5: 1 \mathrm{v} / \mathrm{v})) ; \mathrm{mp}=139.1-139.8^{\circ} \mathrm{C}(\mathrm{EtOH}$ : $\left.\mathrm{H}_{2} \mathrm{O}=2: 1 \mathrm{v} / \mathrm{v}\right) ; \mathrm{IR}\left(\mathrm{v}_{\text {maks, }} \mathrm{cm}^{-1}, \mathrm{KBr}\right), 3410.63$ (OH, bonded); 2935.25 (C-H, stretching, aliphatis); 1704.33, $(\mathrm{C}=\mathrm{O}$, stretching $) ; 1611.02 \quad(\mathrm{C}=\mathrm{C}$, stretching, aromatic); 1459.51 (C-H, bending, aromatis); 1114.87 (C-O, stretching, aromatic), Gas Chromatography (GC): capillary column with constantly flow gas; temperature of injection $=$ $300^{\circ} \mathrm{C}$; split injection mode; column flow 0.5 $\mathrm{mL} /$ minute; gas pressure 8.19 psi; time of retention $\left(t_{\mathrm{R}}\right) 37.338 \mathrm{~min}$; MS (EI-MS, $\mathrm{m} / \mathrm{z}$ ): $430.2\left[\mathrm{M}^{+}\right]$(35\%), 281 (15\%), 207 (34\%), 167 $(100 \%), 122.9(6 \%), 96(6 \%), 73(9 \%)$, dan 44 (8\%). H-NMR (500 MHz, $p$ pm, $\left.\mathrm{CDCl}_{3}\right): \delta 6.37$ $\left(4 \mathrm{H}, s, \mathrm{H}_{9}-\mathrm{Ph} \times 4\right), \delta 5.36(2 \mathrm{H}, s,-\mathrm{OH} \times 2), \delta$ $3.85\left(4 \mathrm{H}, s,-\mathrm{OCH}_{3} \times 4\right), \delta 3.16\left(2 \mathrm{H}, d d, \mathrm{H}_{7 \mathrm{a}}, \mathrm{J}=\right.$ $5.2 ; \mathrm{J}=14.3), \delta 2.53\left(2 \mathrm{H}, d d d d, \mathrm{H}_{2}\right.$ and $\mathrm{H}_{6}, \mathrm{~J}=$ $5.2 ; \mathrm{J}=5.85 ; \mathrm{J}=13 ; \mathrm{J}=13 \mathrm{~Hz}), \delta 2.33(2 \mathrm{H}$, $\left.\mathrm{dd}, \mathrm{H}_{7 \mathrm{~b}}, \mathrm{~J}=5.85 ; \mathrm{J}=14.3 \mathrm{~Hz}\right) \delta 2.10(2 \mathrm{H}$, dddd, $\mathrm{H}_{3 \mathrm{a}}$ dan $\mathrm{H}_{5 \mathrm{a}}, \mathrm{J}=2.6 ; \mathrm{J}=10.35 ; \mathrm{J}=13 ; \mathrm{J}=13.6$ $\mathrm{Hz}), \delta 1.81\left(2 \mathrm{H}, d d d, \mathrm{H}_{4}, \mathrm{~J}=2.6 ; \mathrm{J}=5.85 ; \mathrm{J}=\right.$ 
13.6 $\mathrm{Hz}), \delta 1.35\left(2 \mathrm{H}\right.$, dddd, $\mathrm{H}_{3 \mathrm{~b}}$ and $\mathrm{H}_{5 \mathrm{~b}}, \mathrm{~J}=$ 5.85; $\mathrm{J}=13 ; \mathrm{J}=13 ; \mathrm{J}=13.6 \mathrm{~Hz})$. C-NMR $(125$ $\left.\mathrm{MHz}_{\mathrm{CDCl}}\right): \delta 213.18(\mathrm{C}=\mathrm{O}), \delta 146.96(\mathrm{C}-$ 10), $\delta 133.02$ (C-8), $\delta 131.90$ (C-11), $\delta 105.87$ (C-9), $\delta 56.44$ (C-12), $\delta 53.63$ (C-2 and C-6), $\delta$ 35.90 (C-7), $\delta 35.44$ (C-3 and C-5), and $\delta 25,59$ (C-4).

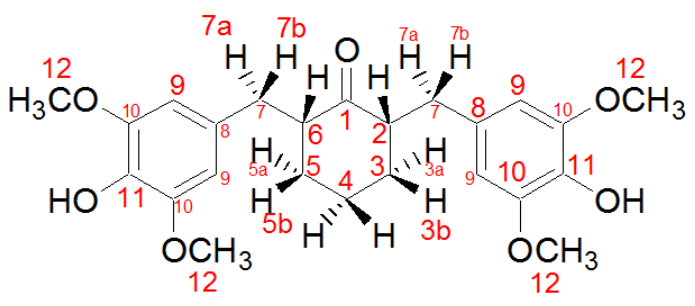

Synthesis of THHGV-7 [TRIVIAL]; 2,6bis-(4'-trofluoromethylbenzil)-cyclohexanon [IUPAC]

HGV-7 (250 mg; $0.6098 \mathrm{mmol})$ in

$\mathrm{MeOH} \quad(5 \mathrm{~mL}), \quad \mathrm{Pd} / \mathrm{C} \quad 10 \% \quad$ (64.883mg; $0.06098 \mathrm{mmol})$, isolated by flash column chromatography (n-hexane:dichloromethane $\left.\left(\mathrm{C}_{6} \mathrm{H}_{14}: \mathrm{CH}_{2} \mathrm{Cl}_{2}=5: 3 \mathrm{v} / \mathrm{v}\right)\right)$, recrystallized from ethanol : water $\left(\mathrm{EtOH}: \mathrm{H}_{2} \mathrm{O}=2: 1 \mathrm{v} / \mathrm{v}\right)$, THHGV-7 as white crystalline powder; yielded $19 \%$ of THTGV-7; $\mathrm{R}_{f}=0.72\left(n-\mathrm{C}_{6} \mathrm{H}_{14}: \mathrm{CH}_{2} \mathrm{Cl}_{2}\right.$ $=5: 3 \mathrm{v} / \mathrm{v}) ; \mathrm{mp}=161.3-162.1^{\circ} \mathrm{C}\left(\mathrm{EtOH}: \mathrm{H}_{2} \mathrm{O}=\right.$ $2: 1 \mathrm{v} / \mathrm{v})$; IR ( $\left.\mathrm{v}_{\max }, \mathrm{cm}^{-1}, \mathrm{KBr}\right): 3045.81(\mathrm{C}-\mathrm{H}$, stretching, aromatic); 2930.39 (C-H, stretching, aliphatic); 1695.53 (C=O, stretching); 1617.88 ( $\mathrm{C}=\mathrm{C}$, stretching, aromatic); and 1326.19 (C-F); Gas Chromatography (GC): capillary column with constantly flow gas; temperature of injection = $300^{\circ} \mathrm{C}$; split injection mode; column flow $0.5 \mathrm{~mL} / \mathrm{min}$; gas pressure 8.19 psi; time of retention $\left(t_{R}\right) 23.004$ minutes; MS (EI-MS, m/z): $414\left[\mathrm{M}^{+}\right]$(42\%); 395.1 (25\%); 255.1 (68\%); 237.0 (38\%); 185.0 $(20 \%) ; 159.0(100 \%)$; and $109.0(22 \%) .{ }^{1} \mathrm{H}-$ NMR (500 MHz, ppm, CD $\left.{ }_{3} \mathrm{OD}\right): \delta 7.53(4 \mathrm{H}, d$, $\left.\mathrm{J}=7.8 \mathrm{~Hz} ; \mathrm{H}_{10}-\mathrm{Ph} \times 4\right) ; \delta 7.36(4 \mathrm{H}, d, \mathrm{~J}=7,8$ $\left.\mathrm{Hz} ; \mathrm{H}_{9}-\mathrm{Ph} \times 4\right) ; \delta 3.19(2 \mathrm{H}, d d, \mathrm{~J}=5.85 \mathrm{~Hz}$ and $\left.14.25 \mathrm{~Hz} ; \mathrm{H}_{7 \mathrm{a}}\right) ; \delta 2.79(2 \mathrm{H}, d d d, \mathrm{~J}=5.85 \mathrm{~Hz} ; \mathrm{J}$ $=12.3 \mathrm{~Hz}$ and $\mathrm{J}=18.15 \mathrm{~Hz} ; \mathrm{H}_{2}$ and $\left.\mathrm{H}_{6}\right) ; \delta 2.51$ $\left(2 \mathrm{H}, d d, \mathrm{~J}=7.75 \mathrm{~Hz}\right.$ and $\left.\mathrm{J}=14.25 \mathrm{~Hz} ; \mathrm{H}_{7 \mathrm{~b}}\right) ; \delta$ $2.04\left(2 \mathrm{H}, m, \mathrm{H}_{3 \mathrm{a}}\right.$ and $\left.\mathrm{H}_{5 \mathrm{a}}\right) ; \delta 1.81-1.78(1 \mathrm{H}, m$, $\left.\mathrm{H}_{4 \mathrm{a}}\right) ; \delta 1.68(1 \mathrm{H}, d d d d, \mathrm{~J}=3.85 \mathrm{~Hz} ; \mathrm{J}=7.8 \mathrm{~Hz}$; $12.95 \mathrm{~Hz}$ and $\left.16.85 \mathrm{~Hz} ; \mathrm{H}_{4 \mathrm{~b}}\right) ; \delta 1.35-1.39(2 \mathrm{H}$, $m, \mathrm{H}_{3 \mathrm{~b}}$ and $\left.\mathrm{H}_{5 \mathrm{~b}}\right) .{ }^{13} \mathrm{C}-\mathrm{NMR}(125 \mathrm{MHz}, p p m$, $\left.\mathrm{CD}_{3} \mathrm{OD}\right): \delta 213.96(\mathrm{C}=\mathrm{O}) ; \delta 146.82(s, \mathrm{C}-11) ; \delta$ $130.92(s, \mathrm{C}-9) ; \delta 129.7 ; 129.45 ; 129.19$ and $128.9\left(q, \mathrm{~J}_{\mathrm{C}, \mathrm{F}}=31.25 \mathrm{~Hz}\right.$ and $\mathrm{J}_{\mathrm{C}, \mathrm{F}}=62.5 \mathrm{~Hz}$, -
$\left.\mathrm{CF}_{3}\right) ; \delta 126.13$ (d, C-10); $\delta 126.10$ (d, C-8); $\delta$ $53.62(s, \mathrm{C}-2$ and C-6); $\delta 36.45$ (s, C-7); $\delta 36.34$ $(s, \mathrm{C}-3$ and C-5); $\delta 26.30$ (s, C-4).

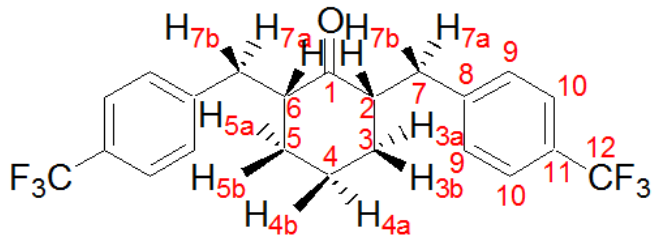

\section{RESULT AND DISCUSSION}

Tetrahydrohexagamavunone-5

(THHGV-5) and Tetrahydrohexagamavunone-7 (THHGV-7) were synthesized by using catalytic hydrogenation reaction on Hexagamavunone-5 (HGV-5) and Hexagamavunone-7 (HGV-7) subsequently. Both reactions were catalyzed by Palladium/Carbon (Pd/C) 10\% as metal catalyst. Palladium/Carbon (Pd/C) 10\% is usually used in this kind of reaction because this catalyst could make the hydrogenation be done at room temperature and certainly accelerate the rate of reaction. According to previous study, $\mathrm{Pd} / \mathrm{C}$ catalyst is more specific than other metal catalyst to reduce $a, \beta$ unsaturated double bond without reduction of its carbonyl functional group (Solomons, 1990).

The hydrogenation on HGV-5 and HGV-7 removed their chromophores (conjugation double bond) which appeared as yellow color and they were transformed into $a, \beta$-unsaturated ketone which appeared as white color compounds, THHGV-5 (23\%) and THHGV-7 (19\%), respectively. Low yields were obtained due to the side products formation. In this kind of reactions, around four side products were present in the reaction mixture. This type of structure make the reduction possible not only on the $\alpha, \beta-$ unsaturated ketone but also reduce the keton to alcohol and alkane (Ritmaleni et al., 2013).

\section{Structure elucidation of THHGV-7 [TRIVIAL]; 2,6-bis-(4'-trofluoromethyl- benzil)-cyclohexanone [IUPAC]}

Hydrogenation means hydrogenation addition. On this reaction the hydrogen was added to the $\alpha, \beta$-unsaturated ketone only the double bond that received the hydrogen. According to the IR spectra, no peak indicated the double bond functional group of $\alpha, \beta$ - 
unsaturated ketone, only aliphatic $\mathrm{C}-\mathrm{H}$ bond at $2935.2 \mathrm{~cm}-1$ can be seen while the $\mathrm{C}=\mathrm{O}$ bond of carbonyl functional group was still can be seen at $1704.3 \mathrm{~cm}^{-1}$. On the H-NMR spectra, there is no alkene peak obtained, there are one peak appeared at 3.16ppm and one peak more appeared at $2.33 \mathrm{ppm}$. These both are peaks of proton of alkane on benzyl functional group. Another proton that can indicate that addition of hydrogen has been successfully added to the double bond is the proton that appeared on $2.53 \mathrm{ppm}$ as doublet of doublet of doublet of doublet and this is corresponding to proton on alpha position of cyclohexanone. Also no carbon alkene was found on the C-NMR spectra. And the other spectra have strongly recommended that the product is THHGV-5.

\section{Structure elucidation of THHGV-5 [TRIVIAL]; 2,6-bis-(4'-Hydroxy-3',5'- dimethoxybenzil)-cyclohexanone [IUPAC]}

Based on the data of GC chromatogram and MS spectra, the level of THHGV-7's purity is about $97.02 \%$. Furthermore, the structure of THHGV-7 was characterized by IR, 1D-NMR ( $\left.{ }^{1} \mathrm{H}-\mathrm{NMR},{ }^{13} \mathrm{C}-\mathrm{NMR}\right)$, and $2 \mathrm{D}-\mathrm{NMR}\left({ }^{1} \mathrm{H}-{ }^{13} \mathrm{C}\right.$ HMQC) Spectroscopy.

THHGV-7 and HGV-7 only differ in $a, \beta$-unsaturated carbonyl. IR spectra shown that no double bond of $\alpha, \beta$-unsaturated ketone was obtained but the $\mathrm{C}=\mathrm{O}$ stretching is still there where a peak at 1695.53 was obtained. ${ }^{1} \mathrm{H}$ NMR spectra of THHGV-7 showed a peak signal at 2.79 ppm (-CH- $a$-carbonil; methyne group), whereas it was undetected on HGV-7's. Furthermore, ${ }^{1} \mathrm{H}-\mathrm{NMR}$ spectra of THHGV-7 showed the existence of $-\mathrm{CH}_{2}-\beta$-carbonyl (methylene group) at $3.19 \mathrm{ppm}\left(\mathrm{H}_{7 \mathrm{a}}\right)$; and 2.51 ppm $\left(\mathrm{H}_{7 \mathrm{~b}}\right) .{ }^{13} \mathrm{C}-\mathrm{NMR}$ spectra showed chemical shift of $-\mathrm{C}-\alpha, \beta$-carbonyl on THHGV-7 (53.62 and $36.45 \mathrm{ppm})$. At last, analyzing THHGV-7 by ${ }^{1} \mathrm{H}-{ }^{13} \mathrm{C}$ HMBC and HMQC Spectroscopy were carried out. These methods analyze the data correlation between atom $\mathrm{H}$ and atom $\mathrm{C}$ spectra of the product that coupling each other. According to that there were some data correlation between atom $\mathrm{H}$ and atom $\mathrm{C}$, such as cross peak diagonal between atom $\mathrm{H}_{2}$ at $\delta$ $2.79 \mathrm{ppm}$ and atom $\mathrm{C}_{2}$ at $\delta 53.62 \mathrm{ppm}$. These data strongly recommend that the product is THHGV-7.

\section{CONCLUSION}

THHGV-5 and THHGV-7 can be synthesized by catalytic hydrogenation reaction on Hexagamavunone-5 (HGV-5) and Hexagamavunone-7 (HGV-7) respectively by using hydrogen gas as hydrogen source, Pd/C $10 \%$ as metal catalyst and methanol as solvent at room temperature with 23 and $19 \%$ yields.

\section{ACKNOWLEDGEMENT}

This research was supported by grants from: Directorate General of Higher Education, Indonesian Ministry of National Education 2012-2014.

\section{REFERENCES}

Murugan P., Pari L., 2007, Protective Role of Tetrahydrocurcumin on Changes in Fatty Acid Composition in Streptozotocin-Nicotinamide Induced Type 2 Diabetic Rats, J.Appl. Biomed., 5, pp. 31-38.

Okada K., Wangpoengtrakul, Tanaka T., Toyokumi S., Uchida K., Osawa T., 2001, Curcumin and Especially Tetrahydrocurcumin Ameliorate Oxidative Stress-induced Renal Injury in Mice, J. Nutr., 131, pp. 2090-2095.

Ritmaleni, Simbara A., 2010, Sintesis Tetrahidropentagamavunon-0, Indonesian J. Pharm, 21, pp. 100-105.

Ritmaleni, Lestari, P., Yuliatun, 2013, Iron (III) chloride, Aluminium chloride and Zinc chloride as catalysts in the synthesis of Tetrahydropentagamavunon-0, Chemistry and Material Research, 3, 2, 32 - 39

Ritmaleni, Sardjiman, Mintariyanti B., Wulandari E., Purwantini I. 2013, Antibacterial Activity of Tetrahydropentagamavunon-0 (THPGV-0) and Tetrahydropentagamavunon-1 (THPGV-1), J.Nat. Sci. Res., 3, 11, 12-18

Ritmaleni, Sardjiman, Widyastani FA., Ardinova SES., Andhini JD. 2013, Identification of Side Products From The Hydrogenation Reaction of bis(substitutedbenzylidene)cyclopentano ne/-cyclohexanone by Using Palladium/ Carbon Catalyst, Chemistry and Material Research, 3, 8, 48-57

Sardjiman SS., Reksohadiprodjo MS., Hakim L., van der Groot H., Timmerman H. 1997, 
1,5-Diphenyl-1,4-pentadiene-3-ones and cyclic analogues as antioxidative agents. Synthesis and structure-activity relationship, Eur. J. Med. Chem., 32, 625630

Sardjiman, 2000, Synthesis and Qualitative Structure Activity Relationship of Some 1,5-Diphenyl-1,4-Pentadiene-3-ones and Cyclic Analogues, Disertasi, Fakultas Farmasi Universitas Gadjah Mada, Yogyakarta.

Sardjiman, Reksohadiprodjo MS., Timmerman H., 2003, Derivatives of Benzylidene Cyclohexanone, Benzylidene Cyclopentanone, Benzylidene Acetone and Their Synthesis, US Patent No. U.S. 6,541,672 B1, Date of Patent 1 April.

Sardjiman, Reksohadiprodjo MS., Timmerman H., 2004, Turunan Benziliden Siklo- heksanon, Benziliden Siklopentanon, Benziliden Aseton dan Pembuatannya, Patent Indonesia, ID 0012940.

Solomons TWG., 1990, Fundamentals of Organic Chemistry, 3rd Ed, John Wiley and Sons Inc., New ork, pp. $243-246$.

Sugiyama Y., Kawakishi S., Osawa T., 1996, Involvement of the $\beta$-diketone moiety in the antioxidative mechanism of tetrahydrocurcumin, Biochem Pharmacol 52: 519-525.

Yoysungneon P., Wirachwong P., Changtam C., Suksamram A., Patumraj S., 2008, Anti-cancer and Anti-angiogenic Effect of Curcumin and Tetrahydro-curcumin on Implanted Hepatocelluler Carcinoma in Nude Mice, World J Gastroenterol, 14(13), pp. 2003-2009. 